\title{
Haematological reference intervals for healthy adults in Bamenda, Cameroon
}

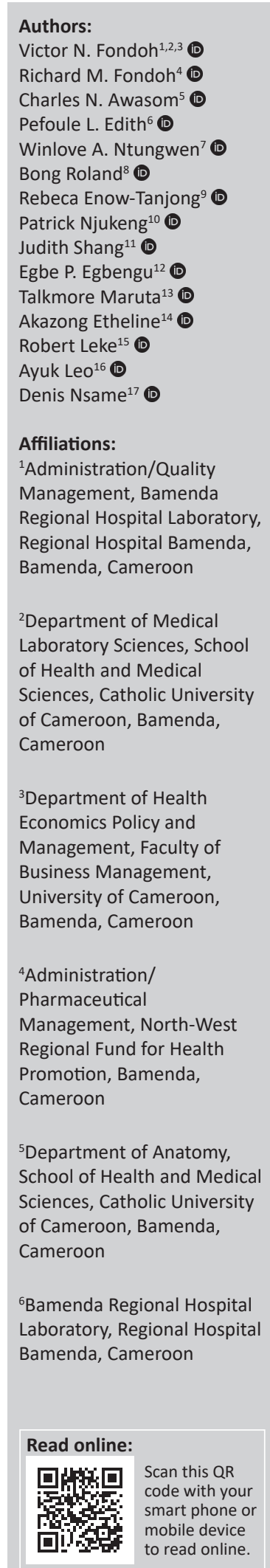

Background: In the era of evidence-based medicine, haematological reference intervals are essential for the interpretation of data for clinical decision-making, monitoring of treatment and research. It is not uncommon that reference intervals used in most African countries have been obtained from published scientific literature, textbooks, reagent/instrument manuals.

Objective: The aim of this study was to determine haematological reference intervals of healthy adults in Bamenda, Cameroon.

Methods: This was a cross-sectional study conducted between June and November 2015. Participants were voluntary blood donors at the Blood Bank Service of the Regional Hospital Bamenda aged between 18 and 65 years. The mean, median and standard deviation of the mean were calculated for each haematological parameter. The 95th percentile reference intervals were determined using the 2.5th and 97.5th percentile. The differences between gender for all the parameters were evaluated using the Kruskal-Wallis test. Significance was determined at the $95 \%$ confidence level.

Results: Out of a total of 340 participants, 202 (59.4\%) were men and 138 (40.6\%) were women. The median red blood cell, haemoglobin, haematocrit and mean cell haemoglobin concentration were significantly higher in men than women $(p<0.001)$. The median white blood cell, absolute lymphocytes count, absolute granulocytes and platelet counts for men were significantly lower than those for women $(p<0.011)$.

Conclusion: We propose that the present established haematological reference intervals in this study should be used for clinical management of patients and interpretation of laboratory data for research in Bamenda.

Keywords: haematological reference intervals; African population; pathogenic infections; haematological abnormalities; Cameroon; Clinical and Laboratory Standard Institute; local reference values; Bamenda.

\section{Introduction}

Haematological reference intervals are essential for the interpretation of data for diagnosis, clinical decision-making and research in this era of evidence-based medicine. It is not uncommon that reference intervals used in most African countries have been obtained from published scientific literature, textbooks, ${ }^{1,2}$ the world wide web, reagent package inserts or instrument manuals. ${ }^{3}$ More often than not, these values have been established from 'Caucasian' populations in Europe or the United States and may not apply to local settings. ${ }^{4,5}$ There is published literature to confirm that haematological reference intervals established in African populations $6,7,8,9,10,11,12,13$

\section{Patient First Laboratory, Columbia, Maryland, United States}

${ }^{8}$ Product Safety/Quality Control Mangement, Geochim Sarl, Cameroon

${ }^{9}$ Department of Medical Laboratory Science, School of Health and Medical Sciences, Catholic University of Cameroon, Bamenda, Cameroon ${ }^{10} \mathrm{Global}$ Health Systems Solutions, Limbe, Cameroon

${ }^{11}$ Laboratory Service, Center for Disease Control and Prevention, Yaoundé, Cameroon

${ }^{12}$ Department of Medicine and Surgery, School of Health and Medical Sciences, Catholic University of Cameroon, Bamenda, Cameroon ${ }^{13}$ East Central and Southern Africa Health Community, Arusha, United Republic of Tanzania

${ }^{14}$ Department of Biochemistry, University of Dschang, Dschang, Cameroon

${ }^{15}$ Department of Medicine and Surgery, School of Health and Medical Sciences, Catholic University of Cameroon, Bamenda, Cameroon ${ }^{16}$ TB-Department, Regional Hospital Bamenda, Bamenda, Cameroon

${ }^{17}$ Administration/Management, Regional Hospital Bemenda, Bamenda, Cameroon Corresponding author: Victor Fondoh, fondohv@yahoo.com

Dates: Received: 07 Apr. 2020 | Accepted: 01 July 2020 | Published: 21 Dec. 2020

How to cite this article: Fondoh VN, Fondoh RM, Awasom CN, et al. Haematological reference intervals for healthy adults in Bamenda, Cameroon. Afr J Lab Med. 2020;9(1), a1193. https://doi.org/10.4102/ajlm.v9i1.1193

Copyright: (C 2020. The Authors. Licensee: AOSIS. This work is licensed under the Creative Commons Attribution License. 
differ significantly from those obtained from Caucasian populations. ${ }^{5,14,15}$ Several factors, including inter- and intrapopulation variation among populations of the same race, age, sex, geographical origin, altitude, genetics, dietary patterns and ethnicity, 7,16,17,18,19,20 account for the differences in these reference intervals. Moreover, pathogenic infections such as HIV, Hepatitis B Virus (HBV), Hepatitis C Virus (HCV), syphilis and some haematological abnormalities generally influence the haematological intervals. ${ }^{9,21,22}$ Besides, the Clinical and Laboratory Standard Institute recommends that clinical laboratories establish and/or verify their local reference values. ${ }^{21,23}$

Cameroon is one of the countries that has been burdened by the malaria and HIV epidemics and that has received multilevel interventions, including access to drugs, and capacity building to manage prevention, treatment and clinical trials. There is little published literature on haematological reference intervals established for the population of Yaoundé in Cameroon. ${ }^{6}$ These intervals cannot be used nationwide since Yaoundé is not representative of the average topography or ecological niche of Cameroon, in general, and Bamenda, in particular. Besides the fact that Bamenda is at a lower altitude than Yaoundé City and differs from other settlements and ethnic groups, there is a need for clinical laboratories to establish and harmonise standard intervals in all localities ${ }^{23}$ for effective clinical decision-making, monitoring of treatment and management of interventions. ${ }^{24,25,26,27}$ The objective of this study was to determine the haematological reference intervals of healthy adults between April and September 2015 in Bamenda, Cameroon.

\section{Methods}

\section{Ethical considerations}

Ethical clearance to carry out this research was obtained from the Institutional Review Board of Regional Hospital Bamenda, Cameroon (Number: 029/APP/RDPH/RHB/ IRB). Participants consented to participate in the study by signing the consent form. Participants could withdraw from the study even after signing the consent form.

\section{Study area}

The study was conducted at the Regional Hospital Bamenda situated in Bamenda, capital of the North-West region of Cameroon, which lies at an altitude between $1100 \mathrm{~m}$ and 1430 $\mathrm{m}$ above sea level. ${ }^{28,29}$ Because of its high socio-economic activity, Bamenda is a cosmopolitan city with settlements of people from diverse ethic backgrounds, ${ }^{30}$ including Mankon, Nkwen, Bamendakwe, Nsongwa, Mbatu, Chomba and Bandza. ${ }^{31}$ As it is situated in the grass fields, most of their diet includes varieties of vegetables. ${ }^{32}$

Regional Hospital Bamenda has standard clinical laboratory and Blood Bank services. The laboratory has been implementing laboratory quality management systems since 2010 and obtained ISO 15189 accreditation by the South African National Accreditation Services in 2017 for
Biochemistry, Serology and Haematology services. ${ }^{33}$ Currently, the Blood Bank service is in the process of certification with the Safe Blood for Africa Foundation.

\section{Research design}

This was a cross-sectional descriptive study conducted between April 2015 and September 2015. The participants were voluntary blood donors who presented during the Regional Hospital Bamenda's voluntary blood donation programme. Blood samples were collected from the Mankon, Nkwen and Bamendakwe settlements. A stratified and clustered sampling method was used. The population was divided into two groups (men and women) and at least 50 samples were collected from participants at each site and from each sex. The blood donors were subjected to several physical and medical screening protocols, as required by the national blood transfusion programme of the Ministry of Health, Cameroon, ${ }^{34}$ in addition to the Clinical and Laboratory Standards Institute guidelines for the establishment of reference intervals ${ }^{21}$ using a questionnaire.

The questionnaire was used to profile eligible donor. Criteria include: the donor should be free from any non-communicable disease, should not have donated blood or had any sexuallytransmitted diseases in the previous three months, should not have been sick or been vaccinated during the previous four months and should not have been on any medication for at least a week before sample collection. Also, the donor should not have smoked on the day of donation or should not have drunk alcohol for at least 24 hours before donation. Female donors should not be pregnant, breastfeeding, or on or expecting their menses within one week of the donation. Furthermore, the donor should be between the ages of 18 and 60 years (women) and 18 and 65 years (men), with blood pressure of $100 \mathrm{mmHg}-140 \mathrm{mmHg} / 60 \mathrm{mmHg}-100 \mathrm{mmHg}$, weight greater than $50 \mathrm{~kg}$, and temperature between $36.0{ }^{\circ} \mathrm{C}-37.5{ }^{\circ} \mathrm{C}$. Blood specimens were collected from donors who were physically fit and who consented to be part of the study. We anticipated enrolling at least 150 participants from each sex to meet the minimum target of at least 120 or more participants after exclusions, as recommended by the Clinical and Laboratory Standards Institute. ${ }^{21}$

\section{Inclusion and exclusion criteria}

Participants that met the inclusion criteria for voluntary blood donation were excluded if they were positive for HIV, HBV, HCV or syphilis. Participants who were sickle cell disease carriers (had the AS genotype) or who had sickle cell disease (had the SS genotype) were also excluded. Participants who did not meet the inclusion criteria, who did not consent, or who withdrew their consent after consenting, were excluded.

\section{Sample collection}

Blood was collected by trained and competent personnel into two $5 \mathrm{~mL}$ vacutainer tubes containing dipotassium ethylene diamine tetraacetic acid (K $\mathrm{K}_{2}$ EDTA). Samples were stored and 
transported to the Blood Bank service of the Regional Hospital Bamenda in a cold chain between $2{ }^{\circ} \mathrm{C}$ and $8{ }^{\circ} \mathrm{C}$ within $2 \mathrm{~h}$ of collection. One tube was used for screening $\mathrm{HIV}, \mathrm{HBV}, \mathrm{HCV}$, syphilis and haemoglobin electrophoresis, and the other for complete blood count analysis. The plasma was separated from the red blood cells in separate tubes within $1 \mathrm{~h}$ of the samples' arrival at the Blood Bank. Both tubes were stored at $4{ }^{\circ} \mathrm{C}-8^{\circ} \mathrm{C}$ for testing the following day.

\section{HIV, hepatitis B virus, hepatitis C virus, syphilis and haemoglobin electrophoresis testing}

Plasma samples were screened at the Blood Bank department of the Regional Hospital Bamenda. The national algorithm of a rapid test for HIV screening in Cameroon was used. ${ }^{35}$ Samples were screened for HIV using the HIV-1/2 Ag/Ab Combo Determine (Alere Medical Co., Ltd, Matsuhidai, Matsudo-Shi, Chiba-ken, Japan) as the first-line test and OraQuick (OraSure Technologies, Inc., Bethlehem, Pennsylvania, United States) as the second-line test. All participants who were HIV-negative with the first-line test were confirmed as negative with the second-line test. Participants who were positive for HIV with the first-line test only were declared positive and excluded. Syphilis was screened using the Rapid Plasma Reagin carbon slide agglutination assay (Cypress Diagnostics, Langdorp, Belgium) and the Treponema pallidum haemagglutination test for the serodiagnosis of syphilis - IMMUTREP ${ }^{\circledR}$ TPHA (Omega Diagnostics LTD, Alva, Scotland, United Kingdom). Hepatitis B virus was screened for using the HBsAg DiaSpot rapid diagnostic test (DIASpot Diagnostics, Jawa Barat, Indonesia) while Hepatitis $C$ virus antigen was detected using the $\mathrm{HCV}$ Ag DiaSpot rapid diagnostic test (DIASpot Diagnostics, Jawa Barat, Indonesia). Haemoglobin electrophoresis was done using the Hospitex Diagnostics (Hospitex Diagnostics Srl, Sesto Fiorentino, Italy) electrophoresis machine.

The haematological analysis was done within $6 \mathrm{~h}$ of sample collection, using the Urit 3300 auto-analyser (Urit Medical Electronic [Group] Co., Ltd, Guilin, China). The instrument was calibrated using Eurocell Diagnostics internal controls (Eurocell Diagnostics, Rennes Cedex, France), following the protocol provided by the manufacturer. The analyser automatically counted and gave a print-out of results for: red blood cells (RBC); haemoglobin (g/dL); haematocrit (\%); mean cell volume; mean cell haemoglobin; mean cell haemoglobin concentration); coefficient of variation for the standard deviation of red cell distribution (\%); standard deviation of red cell distribution; white blood cells (WBC); proportion of lymphocytes (\%), monocytes (\%) and granulocytes $(\%)$; absolute count of lymphocytes $\left(\times 10^{9} / \mathrm{L}\right)$, monocytes $\left(\times 10^{9} / \mathrm{L}\right)$ and granulocytes $\left(\times 10^{9} / \mathrm{L}\right)$; platelets; mean platelet volume; platelet distribution width and plateletcrit.

\section{Quality control}

The Urit 3300 auto-analyser used for the analysis of the specimens went through a vigorous formal verification process following the Clinical Laboratory Standards Institute guidelines $^{21}$ and the policies of the quality management system of the Bamenda Regional Hospital Laboratory. Precision was monitored daily using commercial internal controls (Eurocell Diagnostics, Rennes Cedex, France) and reviewed using a Levey-Jennings control chart. Randox International Quality Assurance Scheme RIQAS (Randox Laboratories Limited, Crumlin, County Antrim, United Kingdom) external quality controls were done bi-monthly to monitor accuracy. The analysis was suspended if the daily commercial internal control failed. The analysis was done by a trained and competent technician.

\section{Data collection}

Data were collected by three trained personnel using a structured data collection format. Data for age, sex and haematological parameters for the participants who were negative for HIV, HBV, HCV and syphilis, with no haemoglobin abnormalities, were collected from the printout of the Urit 3300 auto-analyser. Data were entered into Excel 2007 software (Microsoft Corp., Redmond, Washington, United States) and double-checked for data entry errors by a second person.

\section{Statistical analysis}

The analysis was done using Microsoft Excel 2007 spreadsheet (Microsoft Corporation, Redmond, Washington, United States) and SPSS version 16 software (IBM Corp., Chicago, Illinois, United States). Outliers were eliminated using the box plot function. The median, mean and standard deviation were calculated for each haematological parameter. The 95th percentile reference intervals were determined using the 2.5 th and 97.5 th percentile. The differences between sexes for all the parameters were evaluated using the Kruskal-Wallis test. Significance was determined at the $95 \%$ confidence level.

\section{Results}

Of the 487 individuals who presented for the blood donation campaigns, 147 were excluded as per the exclusion criteria (Table 1). Of the 340 participants included in the study, 202 were male $(59.4 \%)$ and 138 were female $(40.6 \%)$ within the age range of $18-60$ years ( $95 \%$ confidence interval: $31.5 \pm 10.9$; median age $=29$ years). One hundred and thirty-nine participants (40.9\%) were aged 18-25 years, 97 (28.5\%) were aged 26-35 years, 62 (18.2\%) were aged 36-45 years, 35 $(10.3 \%)$ were aged $46-55$ years, and $7(2.1 \%)$ were aged 56-65 years (Figure 1).

The median RBC, haemoglobin, haematocrit and mean cell haemoglobin concentration were significantly higher in men than in women $\left(\mathrm{RBC}: 5.31 \times 10^{12} / \mathrm{L}\right.$ vs. $4.60 \times 10^{12} / \mathrm{L}, p<0.001$; haemoglobin: $14.6 \mathrm{~g} / \mathrm{dL}$ vs. $12.6 \mathrm{~g} / \mathrm{dL}, p<0.001$; haematocrit: $43.9 \%$ vs. $38.3 \%, p<0.001$; and mean cell haemoglobin concentration: $33.1 \mathrm{~g} / \mathrm{dL}$ vs. $32.8 \mathrm{~g} / \mathrm{dL}, p=0.005)$. Although the median mean cell volume and mean cell haemoglobin were higher in men than women (mean cell volume 
$27.6 \mathrm{fL}$ vs. $27.3 \mathrm{fL}, p=1.000$; and mean cell haemoglobin $27.6 \mathrm{pg}$ vs. $27.3 \mathrm{pg}, p=0.147)$, the differences were not statistically significant (Table 2).

TABLE 1: Exclusion criteria applied to the blood donor population, Bamenda, Cameroon, April-September 2015.

\begin{tabular}{lccc}
\hline Exclusion criteria & $\begin{array}{c}\text { Male } \\
\boldsymbol{n = 2 9 9}\end{array}$ & $\begin{array}{c}\text { Female } \\
\boldsymbol{n = 1 8 8}\end{array}$ & $\begin{array}{c}\text { Total } \\
\boldsymbol{N}=\mathbf{4 8 7}\end{array}$ \\
\hline $\begin{array}{l}\text { Rejected from enrolment as blood donors } \\
\text { following the questionnaire }\end{array}$ & 15 & 8 & 23 \\
HIV & 3 & 1 & 4 \\
HBV $\dagger$ & 18 & 6 & 24 \\
Syphilis $\dagger$ & 1 & 3 & 4 \\
HCV & 4 & 2 & 6 \\
AS genotype & 51 & 26 & 77 \\
Outliers & 7 & 4 & 11 \\
Total exclusions $\dagger$ & 98 & 50 & 148 \\
$\begin{array}{l}\text { Population included in the study after } \\
\text { exclusion criteria were applied } \dagger \dagger\end{array}$ & 202 & 138 & 340 \\
\hline
\end{tabular}

HIV, Human Immunodeficiency Virus; HBV, Hepatitis B virus; HCV, Hepatitis C virus; AS, Haemoglobin A and S.

$\dagger$, One donor was positive for both HBV and syphilis.

\pm Number of exclusions based on exclusion criteria.

$\dagger$, Number of participants who were finally enrolled in the study.

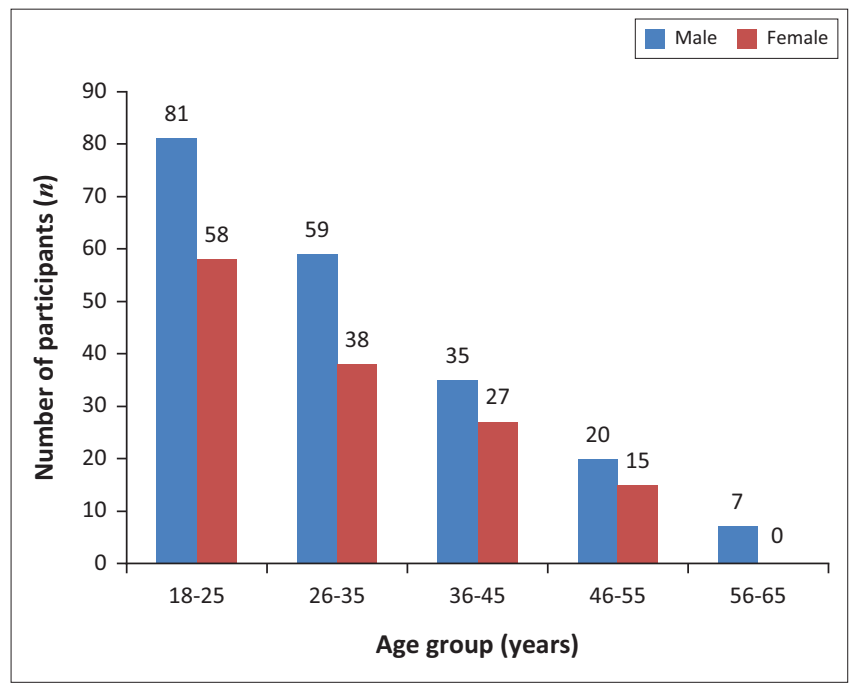

FIGURE1: Percentage distribution of age group (years) and sex of participants in the blood donor population of Bamenda, Cameroon, AprilSeptember 2015.
The median total WBC, absolute lymphocyte count and absolute granulocyte count were significantly lower in men than in women (WBC: $5.0 \times 10^{9} / \mathrm{L}$ vs. $5.5 \times 10^{9} / \mathrm{L}, p=0.002$; absolute lymphocyte count: $2.1 \times 10^{9} / \mathrm{L}$ vs. $2.2 \times 10^{9} / \mathrm{L}$, $p=0.011$; and absolute granulocyte count: $2.4 \times 10^{9} / \mathrm{L}$ vs. $\left.2.8 \times 10^{9} / \mathrm{L}, p=0.002\right)$. Although the absolute median monocyte count for men was relatively higher than that of women, the difference was not statistically significant (Table 3).

Also, the median platelet count was significantly lower in men $\left(231 \times 10^{9} / \mathrm{L}\right)$ than in women $\left(253 \times 10^{9} / \mathrm{L} ; p=0.009\right)$. There was no statistically significant difference between the median mean platelet volume, platelet distribution width and plateletcrit for men as compared to women (Table 4).

\section{Discussion}

The reference interval for haematological parameters, which may serve as a standard for decision-making on clinical laboratory results, treatments and research, were established from 340 participants from Bamenda City, Cameroon. The participants included $202(59.4 \%)$ men and 138 (40.6\%) women aged between 18 and 60 years.

According to our findings, the median RBC, haemoglobin and haematocrit for men were significantly higher than for women. These variations may be attributed to the influence of the hormone androgen on erythropoiesis as well as menstrual blood loss in women. ${ }^{36}$ Our findings are consistent with previous reports in Africa, including Oloume et al. in Cameroon, ${ }^{6}$ Awad et al. in Sudan, ${ }^{38}$ Addai-Mensah et al. in Ghana, ${ }^{7}$ Bakrim et al. in Morocco, ${ }^{8}$ Mulu et al. in Ethiopia ${ }^{13}$ and Yalew et al. in Ethiopia, ${ }^{12}$ Miri-Dashe et al. in Nigeria, ${ }^{36}$ Dosoo et al. in Ghana ${ }^{10}$ and Kueviakoe et al. in Togo, ${ }^{9}$ Karita et al. in Eastern and Southern South Africa ${ }^{21}$ and Menard et al. in Central Africa. ${ }^{20}$ Similar findings have also been reported in the United States. ${ }^{5}$ According to Oloume et al. in the Yaounde study in Cameroon, RBC, haemoglobin, haematocrit and mean cell haemoglobin concentration were lower compared to those obtained in this study. ${ }^{6}$ In their study, however, haemoglobin abnormalities were not

TABLE 2: Erythrocyte parameter reference intervals of healthy adults stratified by sex, Bamenda, Cameroon, April-September 2015.

\begin{tabular}{|c|c|c|c|c|c|c|c|c|}
\hline Parameters & $\begin{array}{l}\text { Red blood cell } \\
\left(\times 10^{12} / L\right)\end{array}$ & $\begin{array}{l}\text { Haemoglobin } \\
\text { (g/dL) }\end{array}$ & $\begin{array}{c}\text { Haematocrit } \\
(\%)\end{array}$ & $\begin{array}{r}\mathrm{MCV} \\
\text { (fL) }\end{array}$ & $\begin{array}{c}\mathrm{MCH} \\
(\mathrm{pg})\end{array}$ & $\begin{array}{l}\text { MCHC } \\
\text { (g/dL) }\end{array}$ & $\underset{(\%)}{\text { RDW_CV }}$ & $\begin{array}{c}\text { RDW-SD } \\
\text { (fL) }\end{array}$ \\
\hline \multicolumn{9}{|c|}{ Combined male and female participants $(N=340)$} \\
\hline Median & 5.00 & 13.8 & 41.8 & 84.3 & 27.5 & 32.9 & 12.2 & 45.0 \\
\hline Mean \pm SD & $5.06 \pm 0.71$ & $13.8 \pm 1.4$ & $41.7 \pm 4.1$ & $83.3 \pm 5.9$ & $27.3 \pm 2.0$ & $33.1 \pm 2.9$ & $12.2 \pm 1.2$ & $44.3 \pm 5.4$ \\
\hline 95th percentile interval & $4.20-6.11$ & $11.3-16.3$ & $34.3-49.3$ & $69.5-93.2$ & $22.6-31.1$ & $31.6-34.6$ & $10.2-14.9$ & $35.5-52.1$ \\
\hline \multicolumn{9}{|l|}{ Men $(N=202)$} \\
\hline Median & 5.31 & 14.6 & 43.9 & 84.3 & 27.6 & 33.1 & 12.2 & 45.0 \\
\hline Mean \pm SD & $5.30 \pm 0.44$ & $14.5 \pm 1.1$ & $43.9 \pm 3.2$ & $83.3 \pm 6.0$ & $27.5 \pm 2.1$ & $33.3 \pm 3.6$ & $12.1 \pm 1.1$ & $44.6 \pm 5.4$ \\
\hline 95th percentile interval & $4.42-6.13$ & $12.4-16.4$ & $37.0-49.8$ & $68.2-93.3$ & $22.4-31.6$ & $31.8-34.6$ & $10.2-14.6$ & $35.5-52.1$ \\
\hline \multicolumn{9}{|l|}{ Women $(N=138)$} \\
\hline Median & 4.60 & 12.6 & 38.3 & 84.3 & 27.3 & 32.8 & 12.2 & 45.0 \\
\hline Mean \pm SD & $4.71 \pm 0.88$ & $12.6 \pm 0.9$ & $38.4 \pm 2.8$ & $83.2 \pm 5.6$ & $27.2 \pm 2.0$ & $32.7 \pm 1.2$ & $12.2 \pm 1.2$ & $43.8 \pm 5.3$ \\
\hline 95th percentile interval & $4.12-5.48$ & $10.9-14.5$ & $32.8-44.2$ & $71.6-92.7$ & $23.1-30.5$ & $31.2-34.4$ & $10.3-15.0$ & $35.5-52.1$ \\
\hline$p$-value & $<0.001 *$ & $<0.001 *$ & $<0.001 *$ & 1.000 & 0.147 & $0.005 *$ & 0.89 & 0.734 \\
\hline
\end{tabular}

$\mathrm{RBC}$, red blood cell; $\mathrm{HGB}$, haemoglobin; $\mathrm{HCt}$, Haematocrit; MCV, mean cell volume; $\mathrm{MCH}$, mean cell haemoglobin; $\mathrm{MCHC}$, mean cell haemoglobin concentration; RDW CV, coefficient of variation of red cell distribution; RDW-SD, standard deviation of red cell distribution width; $N$, number.

$*, p$-values $<0.05$ statistically significant difference between men and women. 
TABLE 3: Leucocyte parameter reference intervals of healthy adults stratified by sex, Bamenda, Cameroon, April-September 2015.

\begin{tabular}{|c|c|c|c|c|c|c|c|}
\hline \multirow[t]{2}{*}{ Parameters } & \multirow{2}{*}{$\begin{array}{l}\text { White blood cell } \\
\left.\qquad \times 10^{9} / L\right)\end{array}$} & \multirow{2}{*}{$\begin{array}{c}\text { Lymphocytes } \\
(\%)\end{array}$} & \multirow{2}{*}{$\begin{array}{c}\text { Monocytes } \\
(\%)\end{array}$} & \multirow{2}{*}{$\begin{array}{c}\text { Granulocytes } \\
(\%)\end{array}$} & \multicolumn{3}{|c|}{ Absolute $\dagger$} \\
\hline & & & & & $\begin{array}{l}\text { Lymphocytes } \\
\left(\times 10^{9} / \mathrm{L}\right)\end{array}$ & $\begin{array}{c}\text { Monocytes } \\
\left(\times 10^{9} / L\right)\end{array}$ & $\begin{array}{c}\text { Granulocytes } \\
\left(\times 10^{9} / L\right)\end{array}$ \\
\hline \multicolumn{8}{|c|}{ Combined male and female participants $(N=340)$} \\
\hline Median & 5.3 & 41.6 & 8.6 & 49.4 & 2.1 & 0.4 & 2.6 \\
\hline Mean \pm SD & $5.4 \pm 1.4$ & $42.1 \pm 7.4$ & $8.6 \pm 1.4$ & $49.2 \pm 7.8$ & $2.3 \pm 0.7$ & $0.5 \pm 0.1$ & $2.7 \pm 0.8$ \\
\hline 95th percentile interval & $3.2-8.3$ & $29.2-57.9$ & $6.0-11.4$ & $33.3-63.4$ & $1.3-4.0$ & $0.3-0.8$ & $1.3-4.6$ \\
\hline \multicolumn{8}{|l|}{$\operatorname{Men}(N=202)$} \\
\hline Median & 5.0 & 41.8 & 8.6 & 49.2 & 2.1 & 0.4 & 2.4 \\
\hline Mean \pm SD & $5.2 \pm 1.3$ & $42.1 \pm 7.9$ & $8.6 \pm 1.4$ & $49.1 \pm 8.2$ & $2.2 \pm 0.7$ & $0.5 \pm 0.1$ & $2.5 \pm 0.8$ \\
\hline 95th percentile interval & $3.0-8.2$ & $28.2-58.0$ & $6.0-11.4$ & $33.1-64.8$ & $1.2-3.8$ & $0.2-0.8$ & $1.3-4.5$ \\
\hline \multicolumn{8}{|l|}{ Women $(N=138)$} \\
\hline Median & 5.5 & 41.6 & 8.4 & 50.1 & 2.2 & 0.5 & 2.8 \\
\hline Mean \pm SD & $5.8 \pm 1.3$ & $42.0 \pm 6.7$ & $8.5 \pm 1.5$ & $49.3 \pm 7.2$ & $2.4 \pm 0.7$ & $0.5 \pm 0.2$ & $2.9 \pm 0.8$ \\
\hline 95th percentile interval & $3.6-8.3$ & $30.6-56.9$ & $6.0-11.4$ & $34.0-62.4$ & $1.5-4.1$ & $0.3-0.9$ & $1.5-4.7$ \\
\hline
\end{tabular}

$\mathrm{SD}$, standard deviation; WBC, white blood cell; $N$, number.

$*, p$-values $<0.05$ statistically significant difference between men and women.

$\dagger$, number.

TABLE 4: Platelet parameter reference intervals of healthy adults stratified by sex, Bamenda, Cameroon, April-September 2015.

\begin{tabular}{|c|c|c|c|c|}
\hline Parameters & $\begin{array}{l}\text { Platelet } \\
\left(\times 10^{9} / \mathrm{L}\right)\end{array}$ & $\begin{array}{c}\text { MPV } \\
\text { (fL) }\end{array}$ & $\begin{array}{l}\text { PDW } \\
\text { (fL) }\end{array}$ & $\begin{array}{l}\text { PCT } \\
(\%)\end{array}$ \\
\hline \multicolumn{5}{|c|}{ Combined male and female participants $(N=340)$} \\
\hline Median & 241 & 10.0 & 11.1 & 0.24 \\
\hline Mean \pm SD & $243 \pm 57.0$ & $10.4 \pm 1.6$ & $11.4 \pm 2.2$ & $0.25 \pm 0.07$ \\
\hline 95th percentile interval & $142.0-354$ & 7.9-13.4 & 7.9-15.3 & $0.14-0.41$ \\
\hline \multicolumn{5}{|l|}{ Men $(N=202)$} \\
\hline Median & 231 & 10.2 & 11.1 & 0.24 \\
\hline Mean \pm SD & $235 \pm 58$ & $10.6 \pm 1.7$ & $11.5 \pm 2.0$ & $0.25 \pm 0.07$ \\
\hline 95th percentile interval & $140-346$ & $8.0-13.4$ & 7.9-15.4 & $0.11-0.42$ \\
\hline \multicolumn{5}{|l|}{ Women $(N=138)$} \\
\hline Median & 253 & 9.9 & 10.8 & 0.24 \\
\hline Mean \pm SD & $253 \pm 54$ & $10.2 \pm 1.5$ & $11.2 \pm 2.3$ & $0.25 \pm 0.06$ \\
\hline 95th percentile interval & $148-367$ & $7.8-13.1$ & 7.7-14.9 & $0.15-0.39$ \\
\hline$p$-value & $0.009 *$ & 0.134 & 0.633 & 0.793 \\
\hline
\end{tabular}

MPV, mean platelet volume; PDW, platelet distribution width; PCT, Plateletcrit; SD, standard deviation; $N$, number.

$*, p$-values $<0.05$ statistically significant difference between men and women.

excluded from their sample collection, considering the $2 \%$ prevalence of sickle cell disease in Cameroon ${ }^{37}$ and may thus account for the low values reported. Besides, Bamenda is at a higher altitude than Yaoundé ${ }^{29,39,40}$ and is situated in the grassland; also, its inhabitants are used to the consumption of vegetables ${ }^{32}$ which have a high iron content that may increase the erythrocyte parameters. At higher altitude, there are physiological changes to humans that compensate for the lower partial pressure of oxygen at higher altitudes. ${ }^{41,42}$ The same reason may account for the relatively lower intervals of $\mathrm{RBC}$, haemoglobin and haematocrit in other countries at lower altitudes compared to those in this study, 7,10,12,17,36 in contrast to higher intervals observed in a study conducted in Ethiopia at higher altitudes. ${ }^{13,43}$ On the other hand, we observed relatively lower intervals of haemoglobin and haematocrit in this study compared to those reported in the United States (Table 5). ${ }^{5}$ This may be attributed to lower ferritin and transferrin saturation among Black participants. ${ }^{44}$ Besides, our study showed a significantly higher mean cell haemoglobin concentration in men than in women, which had also been reported in previous work in Ethiopia. ${ }^{12}$
The median total WBC for men was lower than that for women, and the difference was statistically significant. This may be attributed to the significant difference in the immune system of men and women, associated with the presence of sex hormone receptors on the immune cells. These make women generally more prone to autoimmunity, resulting in lower rates of infection and chronic inflammatory disease. ${ }^{45,46}$ Our findings are in concordance with those reported by Oloune et al. in Yaoundé, Cameroon, ${ }^{6}$ Bakrim et al. in Morocco, ${ }^{8}$ Tekkeşin et al. in Turkey ${ }^{14}$ and Mine et al. in Botswana. ${ }^{47}$

The significantly higher median platelet count in women compared to men is suggestive of variations in hormone type and concentrations in the different genders as well as the effect of erythropoietin released in response to menstrual blood loss and cross-stimulation of megakaryopoiesis. ${ }^{10,36}$ Our findings are consistent with other studies in Africa: Addai-Mensah et al. in Ghana, ${ }^{7}$ Bakrim et al. in Morocco, ${ }^{8}$ Mulu et al. in Ethiopia, ${ }^{13}$ Miri-Dashe et al. in Nigeria, ${ }^{36}$ Dosoo et al. in Ghana ${ }^{10}$ and Kibaya et al. in Kenya. ${ }^{17}$ However, platelet counts in this study were relatively higher than those of other African countries in contrast to higher counts reported in the United States (Table 5). ${ }^{5}$ This could be attributed to genetic factors, compounded by the increased consumption of platelets by Plasmodium spp. in malariaendemic areas. ${ }^{48,49}$

\section{Limitations}

A limitation for this study was that we could not screen for malaria, helminthes or all types of abnormal haemoglobin (except for the AS and SS sickle cell genotypes), and our complete blood analyser could not differentiate the granulocytes into neutrophils, basophils and eosinophils. Also, subclinical conditions which could affect blood parameters were not discernable during sample collection. Furthermore, ethnic and cultural differences that may influence diet and nutritional 


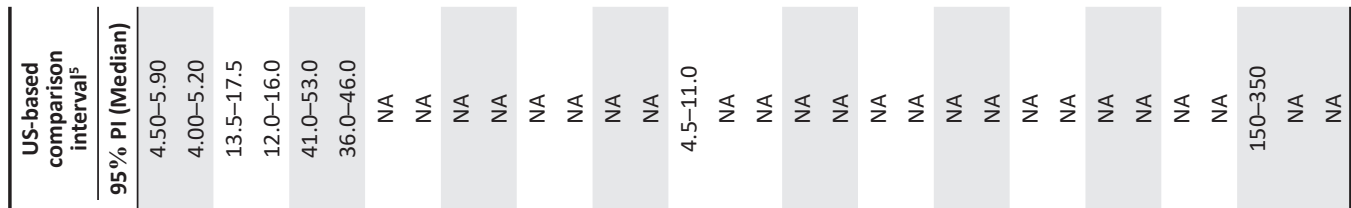

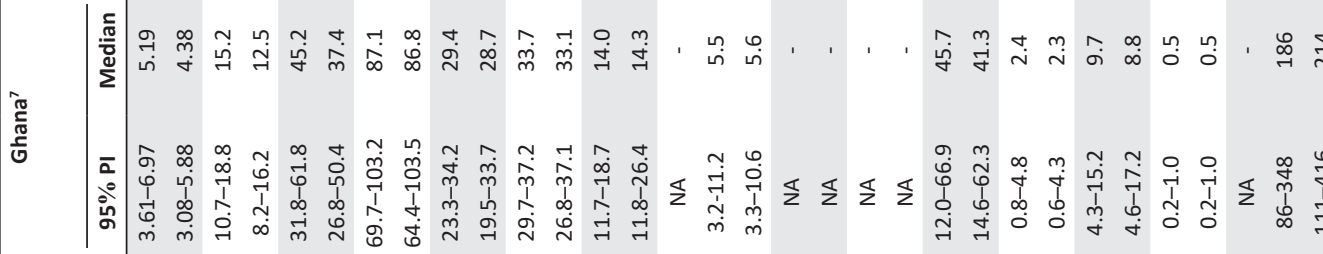

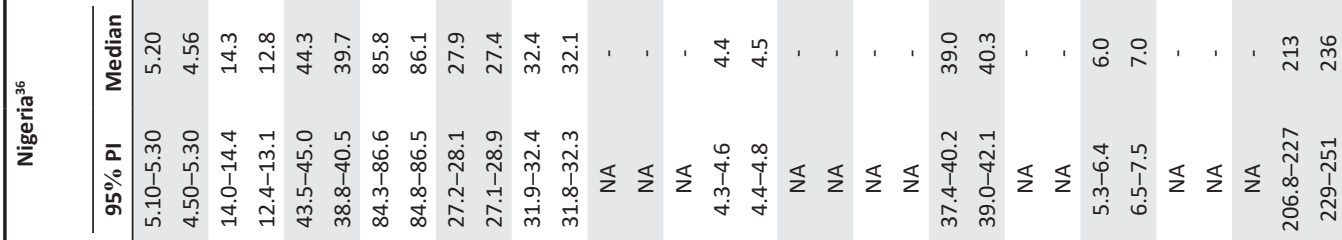

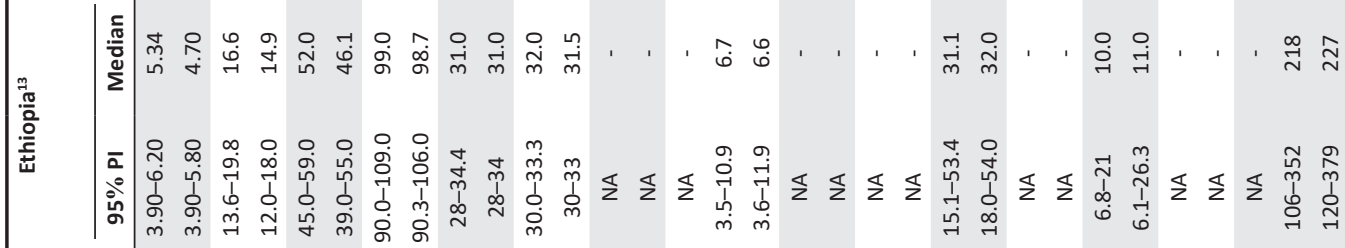

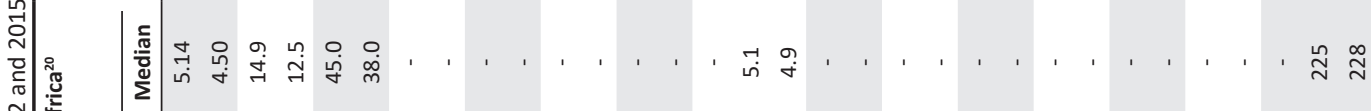

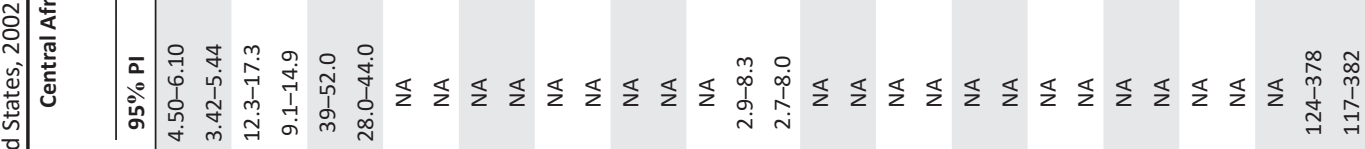

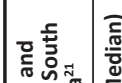

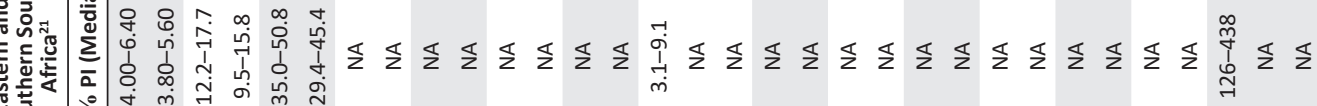
总 离

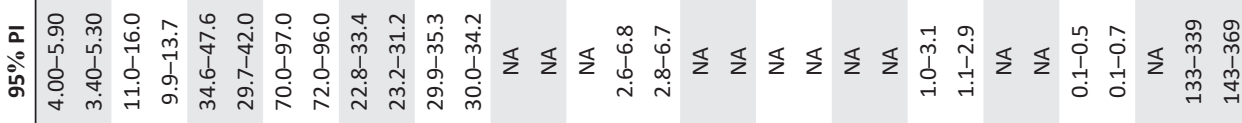

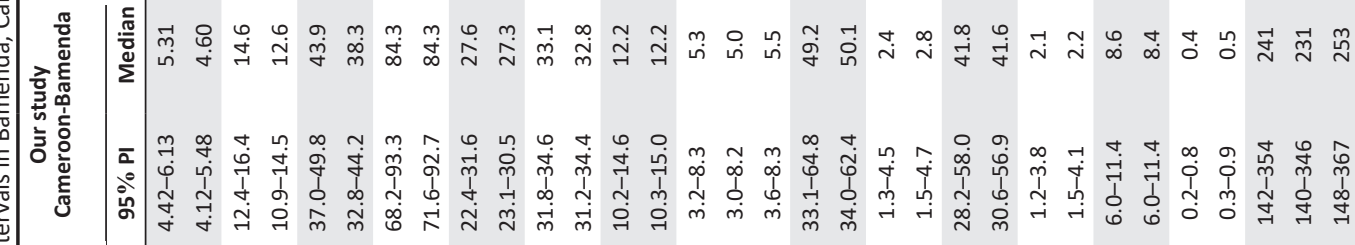

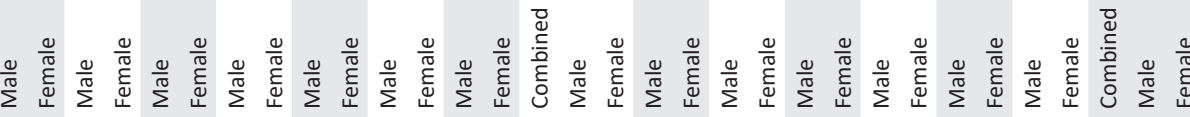

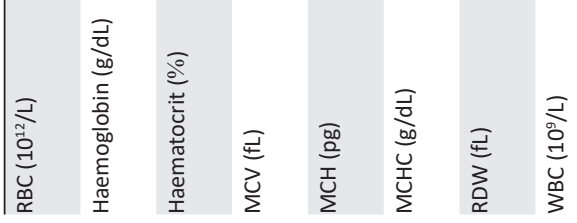


practices could have affected the outcome of our haematological intervals. We could not control for potential selection bias for some people who visited Bamenda and donated blood.

\section{Recommendations}

We recommend that locally generated haematological values should be used as reference intervals in our locality and that each region in Cameroon should determine their haematological reference intervals as recommended by the Clinical Laboratory Standards Institute. ${ }^{21}$

\section{Conclusion}

The haematological reference intervals established in this study are comparable to those obtained in Yaoundé, Cameroon and other studies within and outside of Africa. Any differences in values may be due to differences in latitudes of the localities, race and diet. We propose that the present established haematological reference intervals in this study should be used for clinical management of patients and interpretation of laboratory data for research in Bamenda.

\section{Acknowledgements}

We acknowledge all the participants of this study for voluntarily giving their blood for the establishment of haematological reference intervals for the Bamenda community. Thanks to the Centre for Disease Control and Prevention (CDC), Cameroon, and the Global Health System Solutions, Limbe, for their technical support, the management of the Department of Health Economics, Policy and Management, and the faculty of Health and Medical Science of the Catholic University of Cameroon-Bamenda for academic support during this study. Lastly, we appreciate the staff and management of the Bamenda Regional Hospital Laboratory and the Blood Bank for their wonderful support during the study.

\section{Competing interests}

The authors have declared that no competing interests exist.

\section{Authors' contributions}

V.N.F.(study leader) was responsible for the conceptualisation of the study, study design, supervision (of the experiments, specimen collection, testing, data collection), statistical analysis and final writing. C.N.A. and R.M.F. were responsible for the conceptualisation of the study and statistical analysis. V.N.F., P.L.E. and W.A.N. were responsible for performing the experiments, specimen collection, specimen testing and data collection. B.R. was responsible for providing technical equipment maintenance services. T.M., R.M.F., C.N.A., R.E-T., P.N., B.R., J.S., E.P.E., A.E., R.L, A.L. and D.N. were responsible to help shape the research, adding literature search and critical review of the manuscript.

\section{Sources of support}

This research received no specific grant from any funding agency in the public, commercial, or not-for-profit sectors.

\section{Data availability statement}

Data sharing does not apply to this article as no new data were created or analysed in this study.

\section{Disclaimer}

The views and opinions expressed in this article are those of the authors and do not necessarily reflect the official policy or position of any affiliated agency of the authors.

\section{References}

1. Jameson JL, Weetman AP, Fausi A, et al. Harrison's principles of internal medicine. New York: McGraw-Hill Education, 2005.

2. Lewis SM, Bain BJ, Bates I, et al. Dacie and Lewis practical haematology. E-book. Elsevier Health Sciences; 2006.

3. Koram K, Addae M, Ocran J, et al. Population based reference intervals for common blood haematological and biochemical parameters in the Akuapem north district. Ghana Med J. 2007;41(4): 160-166. https://doi.org/10.4314/gmj. v41i4.55284

4. Giorno R, Clifford JH, Beverly S, et al. Hematology reference values analysis by different statistical technics and variations with age and sex. Am J Clin Pathol. 1980;74(6):765-770. https://doi.org/10.1093/ajcp/74.6.765

5. Kratz A, Ferraro M, Sluss PM, et al. Normal reference laboratory values. N Engl J Med. 2004;351(15):1548-1563. https://doi.org/10.1056/NEJMcpc049016

6. Oloume ME, Mouliom A, Melingui BF, et al. Haematological values in a healthy adult population in Yaoundé, Cameroon. Afr J Lab Med. 2019;8(1):a852. https:// doi.org/10.4102/ajlm.v8i1.852

7. Addai-Mensah O, Gyamfi D, Duneeh RV, et al. Determination of haematological reference ranges in healthy adults in three regions in Ghana. BioMed Res Int. reference ranges in healthy adults in three regions in
2019;2019:1-6. https://doi.org/10.1155/2019/7467512

8. Bakrim S, Motiaa Y, Benajiba M, et al. Establishment of the hematology reference intervals in a healthy population of adults in the Northwest of Morocco (TangierTetouan region). Pan Afr Med J. 2018;29(1):1-18. https://doi.org/10.11604/ Tetouan region). Pan Af
pamj.2018.29.169.13042

9. Kueviakoe IM, Segbena AY, Jouault $\mathrm{H}$, et al. Hematological reference values for healthy adults in Togo. ISRN Hematol. 2010;2011:1-5. https://doi. org/10.5402/2011/736062

10. Dosoo DK, Kayan K, Adu-Gyasi D, et al. Haematological and biochemical reference values for healthy adults in the middle belt of Ghana. PLoS One. 2012;7(4):1-9. https://doi.org/10.1371/journal.pone.0036308

11. Ramezani A, Shams M, Zarinfar N, et al. Hematological reference values for healthy males in the central part of Iran. Iran J Pathol. 2014;9(1):50-55.

12. Yalew A, Terefe B, Alem M, et al. Hematological reference intervals determination in adults at Gondar university hospital, Northwest Ethiopia. BMC Res Notes. 2016;9(1):483. https://doi.org/10.1186/s13104-016-2288-8

13. Mulu W, Abera B, Mekonnen Z, et al. Haematological and CD4+ T cells reference ranges in healthy adult populations in Gojjam zones in Amhara region, Ethiopia. PLoS One. 2017;12(7):1-13.

14. Tekkeşin N, Bekoz $\mathrm{H}$, Tukenmez $\mathrm{F}$. The largest reference range study for hematological parameters from Turkey: A case control study. J Clin Exp Investig. 2014;5(4):548-552.

15. Troussard X, Vol S, Cornet E, et al. Étude des valeurs normales de l'hémogramme chez l'adulte: Un besoin pour une meilleure interprétation et pour l'accréditation du laboratoire. Ann Biol Clin. 2014;72(5):61-81.

16. Buchanan AM, Muro FJ, Gratz J, et al. Establishment of haematological and immunological reference values for healthy Tanzanian children in Kilimanjaro Region. Trop Med Int Health. 2010;15(9):1011-1021. https://doi.org/10.1111/ j.1365-3156.2010.02585.x

17. Kibaya RS, Bautista CT, Sawe FK, et al. Reference ranges for the clinical laboratory derived from a rural population in Kericho, Kenya. PLoS One. 2008;3(10):1-7.

18. Lawrie $D$, Coetzee $L M$, Becker $P$, et al. Local reference ranges for full blood count and CD4 lymphocyte count testing. S Afr Med J. 2009;99(4): 243-248.

19. Otahbachi M, Simoni J, Simoni G, et al. Gender differences in platelet aggregation in healthy individuals. J Thromb Thrombolysis. 2010;30(2):184-191. https://doi. org/10.1007/s11239-009-0436-x

20. Menard D, Mandeng MJ, Tothy MB, et al. Immunohematological reference ranges for adults from the Central African Republic. Clin Diagn Lab Immunol. 2003;10(3):443-445.

21. Karita E, Ketter N, Price MA, et al. CLSI-derived hematology and biochemistry reference intervals for healthy adults in eastern and southern Africa. PLoS One. 2009;4(2):1-14. 
22. Segbena AY, Prehu C, Wajcman $\mathrm{H}$, et al. Hemoglobins in Togolese newborns: $\mathrm{Hb}$ S, Hb C, Hb Bart's, and $\alpha$-Globin gene status. Am J Hematol 1998.59(3):208-213. https://doi.org/10.1002/(SICI)1096-8652(199811)59:3<208::AID-AJH5>3.0.CO;2-R

23. Appold K. Determining laboratory reference intervals: CLSI guideline makes the task manageable. Lab Med. 2009;40(2):75-76.

24. Alemnji G, Mbuagbaw J, Folefac E, et al. Reference physiological ranges for serum biochemical parameters among healthy Cameroonians to support HIV vaccine and related clinical trials. Afr J Health Sci. 2010;17(3\&4):75-82.

25. Ngo-Matip M-E, Pieme CA, Azabji-Kenfack M, et al. Impact of daily supplementation of Spirulina platensis on the immune system of naïve HIV-1 patients in Cameroon: A 12-months single blind, randomized, multicenter trial. Nutr J. 2015;14(1):70 https://doi.org/10.1186/s12937-015-0058-4

26. Sumbele IUN, Kimbi HK, Ndamukong-Nyanga JL, et al. Malarial anaemia and anaemia severity in apparently healthy primary school children in urban and rural settings in the Mount Cameroon area: Cross sectional survey. PLoS One. 2015;10(4):1-17.

27. Nkuo Akenji T, Ntonifor N, Ching J, et al. Evaluating a malaria intervention strategy using knowledge, practices and coverage surveys in rural Bolifamba, southwest
Cameroon. Trans R Soc Trop Med Hyg. 2005;99(5):325-332.

28. Kometa SS, Akoh NR. The Hydro-geomorphological implications of urbanisation in Bamenda, Cameroon. J Sustain Dev. 2012;5(6):64-73. https://doi.org/10.5539/ jsd.v5n6p64

29. Chi A. Human interference and environmental instability: Addresing the environmental consequences of rapidurban growth in Bamenda, Cameroon. Environ Urban. 1998;10(2):161-173. https://doi.org/10.1630/095624798101284527

30. Review WP. Cameroon population 2020. c2019 [cited 2020 Mar 13]. Available from: https://worldpopulationreview.com/countries/cameroon-population/

31. Immanuel J. Lack of basic services in the tourism industry: A study of stakeholders perspectives in Bamenda, Cameroons. c2019 [cited 2020 August 10]. Available from: https://www.diva-portal.org/smash/get/diva2:1337743/FULLTEXT01.pdf

32. Asongwe GA, Yerima BP, Tening AS. Vegetable production and the livelihood of farmers in Bamenda Municipality, Cameroon. Int J Curr Microbiol App Sci. 2014;3(12):682-700.

33. SANAS. 2017 [cited 2020 Mar 13]. Available from: https://www.sanas.co.za/ Pages/index.aspx

34. Nchinda E, Tagny C, Mbanya D. Blood donor haemovigilance in Yaoundé, Cameroon. Transfus Med. 2012;22(4):257-261. https://doi.org/10.1111/j.13653148.2012.01161.x

35. NACC. National guildeline on the prevention and mangement of HIV in Cameroom [homepage on the Internet]. c2015 [cited 2020 Mar 13]. Available from: https:// aidsfree.usaid.gov/sites/default/files/cameroon_art_2015.pdf
36. Miri-Dashe $\mathrm{T}$, Osawe $\mathrm{S}$, Tokdung $\mathrm{M}$, et al. Comprehensive reference ranges for hematology and clinical chemistry laboratory parameters derived from normal Nigerian adults. PLoS One. 2014;9(5):1-10. https://doi.org/10.1371/journal. Nigerian adults.

37. Bros $B$, Leblanc $T$, Barbier-Bouvet $B$, et al. Lecture critique de l'hémogramme: valeurs seuils à reconnaître comme probablement pathologiques et principales variations non pathologiques. National Agency of Accreditation and Evaluation of variations non pathologiques. Nation
Health (ANAES). September 1997.

38. Awad KM, Bashir AA, Osman AA, et al. Reference values for hemoglobin and red blood cells indices in Sudanese in Khartoum State. International Journal of Health Sciences and Research. 2019;9(1):210-214.

39. Tchamba A, Nzeukou A, Tené $R$, et al. Building potentials of stabilized earth blocks in Yaounde and Douala (Cameroon). Int J Civil Eng Res. 2012;3(1):1-14.

40. Ngon GN, Yongue-Fouateu R, Bitom D, et al. A geological study of clayey laterite and clayey hydromorphic material of the region of Yaoundé (Cameroon). A prerequisite for local material promotion. J Afr Earth Sci. 2009;55(1-2):69-78. https://doi.org/10.1016/j.jafrearsci.2008.12.008

41. Windsor JS, Rodway GW. Heights and haematology: The story of haemoglobin at altitude. Postgraduate Med J. 2007;83(977):148-151.

42. Whitacre CC. Sex differences in autoimmune disease. Nat Immunol. 2001;2(9):777-780. https://doi.org/10.1038/ni0901-777

43. Scheinfeldt LB, Soi S, Thompson S, Ranciaro A, et al. Genetic adaptation to high altitude in the Ethiopian highlands. Genome Biol. 2012;13(1):R1.

44. El-Hazmi MA, Warsy AS. Normal reference values for hematological parameters, red cell indices, $\mathrm{HB} A 2$ and $\mathrm{HB} F$ from early childhood through adolescence in Saudis. Ann Saudi Med. 2001;21(3-4):165-169.

45. Bupp MRG. Sex, the aging immune system, and chronic disease. Cell Immunol. 2015;294(2):102-110. https://doi.org/10.1016/j.cellimm.2015.02.002

46. Bhatia A, Sekhon HK, Kaur G. Sex hormones and immune dimorphism. Sci World J. 2014;2014:1-9.

47. Mine M, Moyo S, Penny Stevens KM, et al. Immunohaematological reference values for HIV-negative healthy adults in Botswana. Afr J Lab Med. 2012;1(1):1-7. https://doi.org/10.4102/ajlm.v1i1.5

48. Asare-Ntow K, Kuma G, Adjei R. Analysis of Malaria diagnosis and treatment data amongst pregnant women after the implementation of Test-Treat-Track policy, Brong Ahafo Region-2017. Int J Infect Dis. 2018;73:171-172. https://doi. org/10.1016/j.ijid.2018.04.3803

49. Hoffbrand A, Moss P, Pettit J. Essential haematology, 2006. Volume 5. Malden MA: Blackwell Publishing, 2006; p. 249. 